\title{
Violation of the national campaign teamsness principles and the national winning agency in the presidential and vocational presidential polemic of the 2019 president of Indonesia.
}

\author{
Roli Stambo',Agustina ${ }^{2}$, Winda Azmi $^{3}$ \\ \{roli_stambo@yahoo.com ${ }^{1}$, tien_agustina08@yahoo.com ${ }^{2}$,windaazmy1991@gmail.com ${ }^{3}$ \} \\ ${ }^{1,2,3}$ Universitas Negeri Padang, Jl. Prof. Dr. Hamka Air Tawar Padang Sumatera Barat \\ 25131, Indonesia
}

\begin{abstract}
Abstract. Presidential and vice-presidential elections invite a lot of public attention, especially in the media expressed by the two different teams. Therefore, this research tries to see a form that replaces the principle of politeness in the speech of the National Campaign Teams and the National Candidate Body for Indonesia's 2019 presidential and vice-presidential candidates in a polemic on the online news portal. This study uses qualitative considerations with descriptive methods. Analyzing data uses Miles and Huberman's theory with three hi: reducing data, presenting data, and drawing conclusions. The results of the research show that who are more dominant politicians oppose the principles of politeness for the progress of others or the intended parties. Violation of the politeness principle occurs in six maxims. Of the six maxims in the politeness principle, the most violated are the maxims of praise and the least violated are the maxims of generosity and generosity..
\end{abstract}

Keywords: politeness principles, speech acts, online news portals.

\section{Introduction}

The 2018 and 2019 local elections were the years of the democratic party for the Indonesian people. In 2019 the first time the presidential election and the election of legislators are held simultaneously. The party of democracy is felt now. This is due to the many media that highlight the development of politicians in print and online mass media. Candidates for president and vice president along with the National Campaign Team (TKN) and the National Winning Agency (BPN) were the main highlights in political discourse. Candidates for Indonesian President and Vice President 2019-2024. Ir. H. Joko Widodo, who is the 7th President of Indonesia, is paired with Prof. Dr. K. H. Ma'ruf Amin from ulama and politicians. Furthermore, Lieutenant General (Purn) H. Prabowo Subianto Djojohadikusumo came from Indonesian politicians and military officers paired with H. Sandiaga Salahuddin Uno, B.B.A., M.B.A. who came from Indonesian businessmen and politicians.

Speech acts are a basic unit of communication. In communicating activities, the speaker and the speech partner do the speech act not only to convey or say the sentence but also to be followed by the action. [1] states that a speech act is an act that is displayed through utterance 
in a communication process. Therefore, to act by the wishes or can be realized, the speaker and speech partner need to consider various aspects [2]. The speech acts of both the presidential candidates and the TKN and BPN on the online news portal were highlighted by all parties. Based on observations made, some public speech acts published in online news portals contain violations of politeness in the language in the last decade. Likewise, [3] considers that politeness in the language is an attempt to make the beliefs and opinions that are not polite to be as small as possible by obeying the principle of politeness in language. This has become a serious phenomenon in the world of Indonesian politics.

The contributing factor to this is the use of language for the benefit of even political gain. This is evident from the following studies. In Indonesia, recently based on the research of [4], it has been proven that verb violence in DKI Jakarta's local election discourse. The research concluded that generally, politicians are less polite in discussing politics in the mass media while the people are more polite in commenting politics on social media. In Liberia, [5] revealed that the language used by the media to report on the activities of women political leaders tends to show they are 'violating' the world of politics. In Romania, [6] stated that a discourse analysis for the Cluj District Council presidency, Romania in the 2012 local election campaign, the overall message of his campaign was negative, but his speeches highlighted several positive aspects. In Indonesia, [7] with the results of his research shows that language is a powerful communication tool that can be used by many people to persuade. In the courtroom, for example, lawyers use language to convince a jury that their client is right even though the client is not always right.

Human life can never be separated from politics. So, it can be said that TKN and BPN both presidential candidates are role models for the community. Of course, the words of TKN and BPN can affect the electability of the two presidential candidates if language politeness is not obeyed. However, not a few who feel less polite, rude, and tend to distort the facts. This is evidenced by several research results, including [8] explaining that the many uses of language that are not polite and cause terrible effects on public discourse that are vital for someone full of democratic considerations. [9] in his research shows that to express the identity of politicians not only use first-person pronouns but also use Twitter handles, hashtag nouns or proper nouns, referring themselves to third people. The same thing is also done in Indonesia, [10] in his research results are in three levels, namely the comments of politicians at the level of 'impolite', at the level of 'impolite', and in the position of 'polite'. Other research on this matter in Indonesia shows that language in politics almost loses meaning because it has become a means to swear, revile, attack, even bring down other people or political opponents [4].

From several studies in various countries, it can be concluded that in general politicians use language for political purposes. However, there are differences in each of these studies. The difference lies in the object of research, namely TKN and BPN of the two Indonesian presidential candidates in 2019. Also, previous researchers saw politeness in a language only through the principle of politeness being obeyed or violated. Whereas in this study, to see the illocutionary acts of TKN and BPN the two presidential candidates went through three formulations, namely in terms of types of speech acts, speech strategies, and politeness principles.

Excerpts delivered by TKN and BPN of the two presidential candidates are widely published in the online news portal Pinterpolitik.com. The quotations include sentences that violate politeness in language. The online news portal Pinterpolitik.com routinely makes infographics of both presidential candidates, TKN and BPN, especially in terms of language quotes. This makes it easy to understand the intentions of the two presidential candidates, 
TKN, and BPN. Also, online news portals offer convenience and speed in accessing news or information in them [11].

Responding to the statement delivered by Prabowo in the 212 Reunion event on December 2, 2018, which misprinted the blessings of the Prophet Muhammad, led to comments from Inas N. Zubir who was a Jokowi-Maa'ruf TKN "Prabowo was unable to say 'Shallallaahu Alayhi Wa Sallam' so that it became ' sallalla hulaihi wa sallam 'Evidence that he never paid tribute to the Prophet Muhammad. The phrase is an expressive speech act in the form of an accusation. The speech strategy used was direct. This directly accuses the speech partner even though it has not been proven. The speech also violates the principle of the maxim of praise, because of the speech delivered in the form of ridicule or demeaning other parties.

Following this, Suhud Aliyudin, BPN spokesman Prabowo-Sandi commented, "What's the difference with Al Fatekah? I think that's something that can be fixed together. " The expression is a representative speech act in the form of an opinion. The spoken strategy used is a vague strategy using signals to attack the opposing camp. In this opinion, he also insinuated the other TKN camps. This is a violation of the politeness principle of maxim language agreement.

From these data, it can be concluded that whether or not the candidates for president and deputy along with TKN and BPN in delivering speeches or opinions in public will have an impact on the community. The politeness of the language of the presidential candidates is something that must be obeyed by both candidates. Language politeness is related to politeness, respect, good attitude or appropriate behavior in daily life. Therefore, according to [12], courtesy in the form of speech or politeness of language is not solely the main motivation for speakers to speak, but also is a regulating factor that maintains correctly, is pleasant and is not in vain.

If the presidential and vice-presidential candidates, as well as TKN and BPN, were not polite in speaking, then the public as a listener or reader will wonder the truth and will become polemic. So, the presidential and vice-presidential candidates in delivering speeches or opinions must choose his speech. Based on these descriptions, the researchers felt it was necessary to examine the speech acts in the polemic of TKN and BPN candidates for president and vice president 2019 in the online news portal. Speech acts are mostly used by presidential and vice-presidential candidates as well as TKN and BPN in speeches and writing. Based on the background and the phenomenon, this research is important to be studied further in order to reveal how the politeness of the TKN language in expressing their aspirations in the online news portal. So, this research discusses the problem with the title "Violation of the Principle of Politeness Prudence of the National Campaign Team and the National Winning Agency in the Polemic of Presidential Candidates and Vice President of Indonesia 2019".

\section{Method}

The This research is a qualitative descriptive study. This type of qualitative research intends to describe as clearly as possible the object under study, as well as describe the overall, systematic and accurate data [13]. The method used in this research was the descriptive method. In this study, the main instrument is the researcher himself or a member of the research team. In the process of collecting data, researchers use tools in the form of computer media to search, download, and store data. In addition, it is also to create data inventory format sheets, data identification format sheets, and data classification format sheets. The sheet is used for analyzing the politeness of the TKN and BPN speaking 
Indonesian presidential and vice-presidential candidates in 2019 in the online news portal Pinterpolitik.com.

The data in this study are sentences delivered by TKN presidential candidates and vicepresidential candidates which contain controversy and cause polemics on both TKN and BPN camps. That is because the speech of the presidential and vice-presidential candidates and TKN and BPN are key polemic sentences about the topics discussed. The team was divided into two groups, namely the TKN and BPN groups. TKN is a team of presidential candidate pairs Jokowi and Ma'aruf, while BPN is a team of presidential candidate pairs Prabowo-Sandi. The data source of this study was taken from the speech of TKN and BPN Candidates for Indonesian President and Vice President 2019. The speech acts were published in the online news portal, especially Pinterpolitik.com from December 2018 to March 2019.

Data collection techniques in this study were collected by the use of documentation techniques. The data is collected by searching for speeches by the 2019 Indonesian presidential and vice-presidential candidates, TKN, and BPN published in the online news portal Pinterpolitik.com, then the data is sorted. Furthermore, the existing data is matched with the theory used by the researcher. The following steps are taken by researchers in collecting data. First, Indonesia's presidential and vice-presidential candidates 2019, TKN, and BPN. Second, do an inventory and classification of data. Third, mark the data entered into the criteria and record the data that has been marked into the format.

The qualitative data analysis technique was inductive. Data analysis techniques are guided by the opinions expressed by Miles \& Huberman [14], which provide three stages, namely by reducing data, presenting data, and drawing conclusions from existing data. Data reduction means summarizing. The reduction is done to simplify the data. Next is to present data. Presentation of data can be done in the form of tables, graphs, and the like. After the data presentation, final conclusions are drawn

This research is proposed in theory, but it is not intended as a guide for all researchers in studying various phenomena contained in speech that uses politeness elements, namely types of speech acts, speech strategies and the principle of politeness in language to find the politeness of the TKN-speaking Indonesian presidential and vice-presidential candidates in 2019 contained in the online news portal Pinterpolitik.com.

\section{Result and discussion}

\subsection{Result}

The problem that will be discussed in this research is the form of violation of the politeness principle of the National Campaign Team and the National winning Agency for the candidates for the president and vice president of Indonesia in 2019 in a polemic on the online news portal. From the identification of data in accordance with the problems raised, the following data classification was obtained.

Table 1. Results of data analysis

\section{Principle of Politeness}




\begin{tabular}{|lc|} 
Wisdom & 5 \\
Generosity & 2 \\
Modesty & 36 \\
Deal & 4 \\
Conclusion & 4 \\
Jumlah & 0 \\
\hline
\end{tabular}

Based on table 1, it can be concluded that from 106 data there are 51 data that violate politeness principles. The data is divided into five forms of violation of the principle of modesty, namely wisdom, generosity, praise, humility, agreement. While the form of violations of conclusions is not found in the data that has been analyzed. The following will explain the five forms of modesty violations.

Based on these data, it can be explained that out of 212 paragraphs with 602 pairs of registered sentences, there was an error in the use of markers, namely 135 markers of anaphorous reference markers and 107 markers on the conjunction marker of additive meaning relationships. In addition, 20 paragraphs that do not contain markers are obtained.

\subsubsection{Wise Wisdom}

Based on the analysis that has been done, there were 5 utterances of politeness principle that do not comply with the wisdom maxim. The violation can be seen in the following statement.

1. Komisi“"Kami selaku kader dari Pak Prabowo merasa ini suatu bentuk pelecehan.” (Hendarsam Marantoko, Wakil Ketua Advokat Cinta Tanah Air (ACTA) (007/HM:07-01/T3/ BPN)

2. "Sudah lazim dalam dunia politik, kebijakan fiskal (APBN) menjelang pemilu akan menunjukkan pola yang cenderung berbeda dari tahun sebelumnya. Alokasi dana dalam bentuk Cash Transfer/Block Grant akan membengkak jumlahnya di tahun politik" (Fahri Hamzah) (011/FHM:11-01/T1/ BPN).

3. "Saya tak ingat janji tentang nilai rp. Yg saya ingat janji pertumbuhan rata2 7 persen selama 2015-2019” (Faisal Basri) (020/FB:/24-01 T1/TKN).

In speech (1), the speaker does not obey the maxim of wisdom because the speech gives harm to the intended party. This can be seen in the use of sentences ini suatu bentuk pelecehan. This means that the speaker indirectly accuses the interlocutor of harassing the speaker. Furthermore, in speech (2) the speech is in the form of speculation which can be detrimental to certain parties with the form of innuendo delivered. That is because speakers have stated that the amount of fund allocation will swell in the political year, even though it is not certain that the allocation of funds will increase. The speech can be seen in the sentence alokasi dana dalam bentuk Cash Transfer/Block Grant akan membengkak jumlahnya di tahun politik. Sama halnya pada tuturan (3), tuturan tersebut berupa pernyataan mengenai janji yang pernah disampaikan yang dapat merugikan pihak lain karena penutur tidak ingat atau tidak menepati janjinya. Tuturan tersebut dapat dilihat pada kalimat berikut $Y g$ saya ingat janji pertumbuhan rata2 7 persen selama 2015-2019. 


\subsubsection{Maxims of Generosity}

In the analysis carried out there are 2 utterances of politeness principle that do not adhere to the maxim of generosity. The violation can be seen in the following statement.

4. "Saya ingatkan jangan main-main. Tapi kalau masih main-main, saya juga punya mainan" (Moeldoko) (050/MD:13-03/N T1/TKN).

5. "Semalam akun Twitter saya dihack. Sekarang Instagram dan Facebook saya yang dihack..!! Cebong udah mau kalah kayak gini amat..!! JANGAN sampai saya bawa ke POLISI..!! SEGERA BALIKIN Instagram dan Facebook saya atau kalian RASAKAN..!!" kata Ferdinand Hutahaean (069/FH:05-04/ T1/ BPN).

In speech (4), the speaker is seen violating the maxim of generosity. That is because the speaker shows a favorable attitude for himself by threatening his speech partner so as not to mess with him. As in the sentence Tapi kalau masih main-main, saya juga punya mainan. Likewise, in speech (5) speakers also appear to violate the maxim of generosity. This can be seen in the use of sentences JANGAN sampai saya bawa ke POLISI...! SEGERA BALIKIN Instagram dan Facebook saya atau kalian RASAKAN...!! The sentence intends to threaten the interlocutor to return his social media account. Speech can maximize losses for others.

\subsubsection{Maxims Praise}

In the maxim of praise, there are 36 utterances of politeness principle that do not comply with the maxim of praise. Maximum non-compliance is seen in the following statement.

6. "Kami kira itu semacam sindiran keras ke Pak Jokowi" kata Suhud Aliyudin, Direktur Pencapresan (PKS 003/SA:03-01/T4/ BPN).

7. "Spesial capres Prabowo kebohongan paling lebay, selang cuci darah sudah dipakai 40 kali" kata Tsamara Amany, Ketua DPP PSI (007/TA:07-01 /T2/TKN).

8. "Saya jadi paham mengapa pak @jokowi memberikan Grasi kepada Otak Pembunuhan wartawan di Bali itu. Mungkin karena dia adik dr Bupati Bangli saat itu. Bupati Bangli ini dr PDIP. Jadi tak perlu heran lagi atas Grasi itu..." kata Ferdinand Hutahaean (025/FH:29-01/T1/ BPN).

Speech (6), is a speech that does not adhere to the maxim of praise. This, seen in the use of sentences Kami kira itu semacam sindiran keras ke Pak Jokowi. The speech is a conclusion that minimizes respect for other people / institutions in this case Mr. Jokowi. The speaker gives an award in the form of innuendo to the interlocutor. Therefore, the speech is a maxim of praise that does not comply with the maxim. Likewise, utterance (7), it seems that the speaker violates the maxim of praise by criticizing the intended party. The violation can be seen in the sentence Spesial capres Prabowo kebohongan paling lebay, selang cuci darah sudah dipakai 40 kali. The speaker said that Prabowo had done the most lies. Next, speech (8), the speech is in the form of speculation that minimizes respect for other people/institutions/systems, in this case Mr. Jokowi's policy. Speakers compliment by denouncing Jokowi who gave Clemency to Brain Murder journalists in Bali. The speech can be seen in the sentence Mungkin karena dia adik dr Bupati Bangli saat itu. Bupati Bangli ini dr PDIP. Jadi tak perlu heran lagi atas Grasi itu...! 


\subsubsection{Maxims Humility}

The principle of politeness that does not obey the maxim of humility is 4 utterances. Maximum non-compliance is seen in the following statement.

9. Mumpung lg bicarakan UI, bukan UI palsu. Sy alumni UI S1 n S3. Sy mewakili UI debat ASEAN, fellow SIF, $\mathrm{n}$ forum2 internasional. Sy jg memimpin demonstrasi mhs UI, sy Mahasiswa Berprestasi I UI n Berprestasi III Nasional. Sy tentu di pihak berakal sehat: memilih @ prabowo @ sandiuno” kata Fadli Zon (013/FZ:14-01/T1/ BPN).

10. "Ada yang bilang, dia kan juga bagian dari elite? Iya, gue bagian dari elite. Tapi, gw elite yang sadar" kata Prabowo (029/PB:07-02/T2/ BPN)

11. "Kalau diurutkan silsilahnya dari Prabu Siliwangi. Berarti saya mewakili orang Sunda," kata Ma'ruf Amin (070/MA:09-04/ T1/TKN)

In speech (9), it appears that the speaker does not obey the maxim of humility. The violation was seen, in the use of the sentence Sy tentu di pihak berakal sehat: memilih @prabowo@sandiuno. That was, in fact the speaker claims that the other presidential candidates are a party that is not sensible. Furthermore, speech (10) is a speech that violates the principle of humility. This is because speakers use sentences Iya, gue bagian dari elite. Tapi, gw elite yang sadar. The point was that the speaker praises himself by saying he is part of it elit yang sadar. Indirectly, the speaker is arrogant because he is too praising himself. Furthermore, speech (11) is also a speech that violates the principle of humility. Can be proven in sentences Berarti saya mewakili orang Sunda, clearly seen directly by the speaker with confidence he will represent the Sundanese people because it is seen from the pedigree. That is, the speaker believes that he can represent from the Sundanese. The speaker also shows his humility by boasting about being able to represent the Sundanese.

\subsubsection{Maxims Agreement}

The principle of politeness that does not comply with the maxim of agreement as much as 4 utterances. Maximum non-compliance is seen in the following statement.

12. "Kalau Jokowi berkeinginan memberi sebelah matanya Pada Novel Baswedan, mari kita bicara soal penculikan dan pembunuhan masa lalu. Kenapa mata Pak Jokowi? Karena percuma punya mata tapi tak mau melihat persoalan yg mudah ini untuk diselesaikan." Kata Andi Arief (003/AA:03-01 /T1/BPN).

13. "Anak alay politik yg lagi cari perhatian jangan ditanggapi serius, diketawain aja.?" Kata Dahnil A Simanjuntak (007/DAS:07-01 /T1/ BPN).

14. "DITULUNG MENTHUNG" Sudah ditolong ngucapin terimkasih sj tidak, tp malah mukul kepala orang yg menolong. Begitulah kira2 padanan yg pas dgn pengakuan tdk keluar uang saat pilkada itu. Adab yg begini mau dipilih jadi pemimpin? Kalau saya sih pasti TIDAK PILIH..!" kata Ferdinand Hutahaean (021/FH:25-01 /T1/ BPN).

Speech (12) is in the form of utterances that do not comply with the maxim of the agreement because it harms one of the parties. The speech is a challenging sentence that emphasizes fostering agreement / compatibility with other people / groups in this case Mr. Jokowi to give his eyes to Novel Baswedan. That is, the speaker gives his response regarding Mr. Jokowi who cannot solve the problem at hand. These utterances can be seen in sentences Kenapa mata Pak Jokowi? Karena percuma punya mata tapi tau mau melihat persoalan yg 
mudah ini untuk diselesaikan. Similar to speech (13) and (14), the speech is in the form of an invitation that emphasizes fostering agreement / compatibility with other people / groups in terms of audiences so as not to respond to politicians who seek attention and not to choose leaders who are not good. That is, the speaker is too excessive in expressing his opinion without thinking about whether the opinion is approved or not approved by others. The speech can be seen in the sentence Anak alay politik yg lagi cari perhatian jangan ditanggapi serius, diketawain aja.? dan Adab yg begini mau dipilih jadi pemimpin? Kalau saya sih pasti TIDAK PILIH...!

\subsection{Discussion}

Based on the findings that have been presented, it can be concluded that the speech of the TKN and BPN in the polemic of the 2019 Indonesian presidential and vice-presidential candidates in the Online News Portal is quite polite. This can be proven from the data that has been analyzed. Speeches that adhere to the politeness principle by $51 \%$ and speeches that violate the politeness principle by $49 \%$. This means that the TKN and BPN still speak rudely in their speech. Judging from the percentage of speech, the TKN and BPN almost half do a speech that violates the principle of politeness.

The results of this study are still relevant to research conducted by [15], which is about violations of the politeness principle done by politicians. Violation of the politeness principle and function of violation of the politeness principle can be seen from three types of speech acts, namely directive, expressive, and assertive. Also, [16] also said that politicians in Pakistan often use language without paying attention to the listener's face or public self-image. That is, in previous studies, politicians have spoken less politely in expressing their opinions.

Furthermore, [17] who examined the politeness of the participants in the TV Indonesia Lawyers Club (ILC) on TV One such as lawyers, politicians, and highly educated people. That caused a discussion that contained opinions that were sometimes different from the opinions of other participants. However, the method of expressing the opinion of the participants was not a few who had a strong and impolite tone, things that did not contrast with the position or title they were in. [18] also examined the politeness of language in the discourse of political humor in the 2014 Presidential Election on the Twitter account @ CapresJokes. He said that people's behavior did not heed the politeness in language.

Based on this research, it can be concluded that there have been many who have examined the politeness of politicians' language. However, there are differences in each of these studies. The difference lies in the formulation of the problem. Most researchers have previously seen the politeness of language only through the principle of politeness being obeyed or violated by politicians or only seeing what speech strategies politicians use in expressing their opinions. In this study, researchers only used one formula to look at politeness in politicians' language, namely in terms of politeness principles.

\section{Conclusion}

Based on the results and discussion that has been presented, it can be concluded that there are five maxims that were violated by the National Campaign Team and the National winning Agency for the president and vice president of Indonesia in 2019 in polemics on online news portals, namely the maxim of wisdom, maxim of generosity, maxim of praise, maxim of modesty the heart, and the maxim of the deal. From 106 speech data analyzed, there were 51 violations of politeness principle data. The maxim that tends to be violated by the National 
Campaign Teams and the National Winning Agency for the 2019 presidential and vice presidential candidates in the polemic on the online news portal is a maxim of 36 speeches. That is, violations of the five maxims, both from the BPN Agency or TKN there are still 50\% violations of the maxims. As a political figure, to speak in public must speak politely and politely because every utterance that is spoken will affect one's attitude in the community's view. Although the speech is contradictory, it should still speak politely.

\section{Acknowledgements}

This article came about thanks to the help of various parties. The author agrees to thank all those who have contributed to the improvement of this article. The author also thanks to the reviewer who agreed to review this article until it was published.

\section{References}

[1] Yule,G.: Pragmatik, (Terjemahan oleh Indah Fajar WahyuniYogyakarta: Pustaka Pelajar. (2006)

[2] Kwan, Marta, R: Tindak tutur ilokusi dalam negosiosi upacara meminang: kajian etnografi komunikasi” Jurnal Bahastra, 37(1), 58 -72. (2017)

[3] Leech, G.: Prinsip-prinsip pragmatik. Jakarta: UI Press. (1993)

[4] Agustina: Kekerasan verbal dalam pilkada DKI: mengungkap tingkat kesantunan masyarakat berwacana politik. International Prosiding Atlantis Press. (2017)

[5] Anderson, J.A., Diabah, G., \& Mensa, P.A.: Powerful woman in powerless language: media mispresentation of African women in politics (the case of Liberia). ELSEVIER: Journal of Pragmatics. 43(10), 2509-2518. (2011),

[6] Iriș, I., \& Drămnescu, B.: Manipulation techniques analysis and its effects in the political speech. Informare Si Documentare: Activitate Stiintifica Si Profesionala, 7, 142-151. (2014)

[7] Supardi, S.: Language power in courtroom: the use of persuasive features in opening statement. Indonesian Journal of Applied Linguistic. 1(6), 70-78. (2016)

[8] Chen, Y. \& Lu, X.: A session-oriented adaptive load blancing algorithm, International Conference on Network and Parallel Computing, pp. 567-663. (2007)

[9] Coesemans, R. : Self-reference by politicians on twitter: strategies to adapt to 140 characters. ELSEVIER: Journal of Pragmatics. 1(116), 37-50. (2017)

[10] Pangestika, W.: Kesantunan berbahasa para politikus dalam wacana politik pilkada DKI Jakarta di portal berita Online. International Prosiding ICLA. (2018)

[11] Dewanti, I. F.: Analisis isi komentar pemberitaan pada portal berita republika online (Studi Analisis Isi Komentar Pemberitaan tentang Pro Kontra Menteri Susi Pudjiastuti pada Portal Berita Republika Online Periode 27 Oktober 2014-13 November 2014). (2015).

[12] Zahid, M.: Kesantunan dalam debat Indonesia Lawyers Club di TV One 2015 Semester Pertama, dalam Jurnal PendidikanVol.2.No. 3, pp, 20-21. (2015)

[13] Sugiyono: Metode penelitian pendidikan. Bandung: Alfabeta. (2009)

[14] Sugiyono: Metode penelitian kuantitatif, kualitatif, dan R\&D. Bandung: Anggota Ikatan Penerbit Indonesia (IKAPI). (2012)

[15] Nisa, Fithratun: Pelanggaran prinsip kesantunan dalam wacana tutur Basuki Tjahaja Purnama (Ahok). Stilistika: Jurnal Bahasa, Sastra, dan Pengajarannya, 1(1). (2016)

[16] Yasmeen, R, Jabeen, M, \& Akram: A. Politeness and the language of Pakistan politicians. Journal of Academic Research Internatioal, 5(3), 245-253. (2014) 
[17] Luthfiyanti, L.: Kesantunan dalam acara tvindonesia lawyers club (ILC) di tvone. Stilistika: Jurnal Bahasa, Sastra, dan Pengajarannya, 2(1). (2017)

[18] Wulandari, B.: Kesantunan Berbahasa dalam Wacana Humor Politik Pada Pilpres 2014 AkunTwitter@ CapresJokes, dalam Jurnal Pendidikan Vol.I No. I, pp, 5-6. (2014) 